\title{
The implementation of the Marine Strategy Framework Directive: Shortcomings and limitations from the Spanish point of view
}

\author{
Juan Bellas \\ Centro Oceanográfico de Vigo, Instituto Español de Oceanografía, IEO, Subida a Radio Faro, \\ 50, 36390 Vigo, Spain \\ E-mail: juan.bellas@vi.ieo.es \\ Tel.: +34 986 492111; fax: +34986498626
}

\begin{abstract}
The Marine Strategy Framework (Directive 2008/56/EC, MSFD) came into force in 2008, confirming the increased political interest in the oceans observed in recent years, and the change in the philosophy of environmental management, which has resulted in the development of many initiatives to guide the conservation, protection and sustainable management of marine ecosystems. This Directive is the key environmental instrument of the European Union (EU) maritime policy, and establishes that Member States shall adopt the necessary measures to achieve or maintain the Good Environmental Status of the marine environment by 2020. The central part of the MSFD is formed by the 'marine strategies', which have to be developed by the Member States for the marine waters under their jurisdiction. The implementation of the MSFD represents a demanding task in the integrative assessment of marine ecosystems. Here we describe the implementation process, and we discuss the institutional framework and the main difficulties and challenges encountered so far, with emphasis on the Spanish context.
\end{abstract}

Key words: Environmental legislation, ecosystem approach, good environmental status, Marine Strategy Framework Directive 


\section{Introduction}

The growing demand for services and resources of marine origin, which often exceeds the response capacity of the oceans, has dramatically increased the impact of human activities on marine ecosystems in recent decades. The intense industrial activity, intensive agriculture and high population density in coastal areas, as well as overfishing, increased exploration and production of oil and gas, and the development of renewable energy sources, are leading to major impacts that threat the health of the oceans [1, 2, 3, 4]. Given the wealth of resources and potential uses of the sea, which in many cases are incompatible with the sustainable use of those resources, in recent years there has been an increasing political interest in the oceans and a change in the philosophy of environmental management $[5,6]$ that has resulted in the development of numerous initiatives to guide the conservation, protection and sustainable management of marine ecosystems.

It is evident that these tasks cannot be undertaken by individual states; in fact, it requires cooperation and development of coordinated actions among countries sharing marine regions through an integrative and multidisciplinary approach. The legal framework is extremely broad and is of great complexity. At the international level, the United Nations Convention on the Law of the Sea [7] constitutes the legal order governing the uses of the sea and provides the basic framework for all aspects of sovereignty, jurisdiction, use and rights, and obligations of the states in relation to the oceans. In Europe, the marine environment has been considered in part within the scope of several environmental Directives such as the Water Framework Directive (WFD), the Habitats Directive (HD) or the Birds Directive (BD) [e.g. 8, 9, 10]. In addition, Regional Seas Conventions such as the OSPAR Convention (www.ospar.org), the Barcelona Convention (www.unepmap.org), the Helsinki Convention (HELCOM, www.helcom.fi) and the Bucharest Convention (www.blacksea-commission.org), have guaranteed for decades supranational cooperation for the protection and conservation of the marine environment, but often there is little coordination among them, and among them and the existing European legislation, or other international agreements such as the Data Collection Framework Regulation for the Common Fisheries Policy (CFP), or the Maritime Spatial Planning. In fact, until now, an integrated policy for the protection of the seas of the 
European Union (EU) had not been developed, revealing an inadequate institutional framework for the management of the marine environment $[11,12]$.

\section{MSFD implementation in Spain}

In this sense, and within the thematic strategy for the Marine Environment of the Sixth Environment Action Programme of the European Community [13], on 15 July 2008 came into force the Directive 2008/56/EC establishing a framework for community action in the field of marine environmental policy or Marine Strategy Framework Directive (referred to as 'MSFD' or 'the Directive' hereafter) [14]. The main objectives of this Directive are to protect and preserve the marine environment, restoring altered ecosystems, and prevent and reduce inputs in the marine environment, in order to gradually phase out pollution.

The MSFD states that Member States must incorporate the provisions of the Directive into their national law. In Spain, the Law 41/2010 on the protection of the marine environment (LPME) [15], is the standard transposing MSFD into national law, adapting the text of the

Directive to the national scenario. The LPME provides the general legal framework for the conservation and protection of the marine environment in Spain, with the aim of achieving the GES and ensuring the sustainable use of marine resources. In addition, this Law includes the regulation of other aspects related to the protection and planning of the marine environment, such as the creation and management of a Spanish network of Marine Protected Areas, and the control of discharges into the sea.

To facilitate the implementation of marine strategies, the LPME establishes, on the basis of particular biogeographic, oceanographic and hydrological characteristics of each region, five subdivisions within these regions and subregions, so called "marine demarcations". The Atlantic region includes the North Atlantic demarcation, the South Atlantic demarcation and the Canary Islands demarcation; whilst the Mediterranean region comprises the LevantineBalearic demarcation and the Gibraltar Strait and Alborán Sea demarcation (including the Exclusive Economic Zone in the northwestern Mediterranean created by Royal Decree 236/2013, of 5 April, BOE. 92 of April 17, 2013) (Figure 1). The complexity of the MSFD 
implementation has been accentuated in Spain by the great dimension of the marine area under Spanish sovereignty or jurisdiction (more than 1 million $\mathrm{km}^{2}$ ).

In Spain, the public consultation process, prior to sending the national report to the EC, was conducted between June 1 and July 15, 2012, through the website of the Ministry of Agriculture, Food and Environment (http://www.magrama.gob.es). In addition, marine strategies' documents were sent to the governments of the autonomic communities, requesting their review, and were submitted for consultation to the Spanish Environmental Advisory Council (CAMA), being finally approved by the Council of Ministers on $2^{\text {nd }}$ November 2012, as indicated by the Resolution of $13^{\text {th }}$ November 2012, of the Secretary of State for the Environment [16]. In this way, it was guaranteed that all stakeholders had the opportunity to participate, involving organisms and environmental management structures, as much as possible.

\section{International coordination}

\subsection{European coordination}

When developing marine strategies, the MSFD demands a regional approach for the management of European seas, and requires the cooperation between Member States and the coordination with third countries, so that the states not only share goods and services provided by the ocean, but also the challenges they will encounter in the pursuit of GES. Such cooperation is essential to ensure that the different elements of marine strategies are consistent within the different marine regions or sub-regions of the EU, since the MSFD provides that the GES has to be achieved at regional or subregional level. To that end, it will be necessary to develop common approaches, bringing together the best technical expertise available.

As a starting point to reach these objectives, the EC adopted an informal coordination program, the Common Implementation Strategy (Common Implementation Strategy, CIS), whose work scheme consists of the following groups (Figure 2):

- Marine Directors: High-level political group for strategic decision-making to ensure the overall implementation of the MSFD in the EU. 
- Committee for the implementation of the MSFD: Committee which decides issues involving Member States commitments, to respond to Article 25 of the MSFD.

- Marine Strategy Coordination Group (MSCG): This group is a forum for discussion of the technical aspects of the MSFD’s implementation, and serves as a link between the Marine Directors groups and the technical Working Groups. The MSCG is responsible for overseeing the activities of the three technical working groups, and informs the Marine Directors.

- Technical working groups: Groups depending on the MSCG, that were established for the preparation of common methods for the implementation of the MSFD:

- Working Group on Good Environmental Status (WG-GES): This group supports Member States in determining the GES, dealing with issues related to the criteria and methodological standards of GES descriptors and indicators.

- Working Group on Data, Information and Knowledge Exchange (WG-DIKE): This group supports Member States in their obligations for notification to the EC.

- Working Group on Economic and Social Assessment (WG-ESA): This group develops common methodologies and strategies for the economic and social analysis of the uses of the sea and of the cost of marine degradation.

- Technical subgroups: Subgroups established within the WG-GES to address emerging areas of special interest. So far, two technical subgroups have been created, the Technical Subgroup on Underwater Noise (TSG-UN) and the Technical Subgroup on Marine Litter (TSG-ML). Their role consist in advising on the standardization of environmental monitoring methods, and providing a forum for sharing principles and good practices about setting targets and assessment methodologies.

The adoption of common criteria and methodological standards is another crucial task to ensure consistency and to guarantee the comparability of the GES achievement within different marine regions or subregions. In order to do this, the EC, counting with the support of the Joint Research Centre (JRC) and the International Council for the Exploration of the Sea (ICES), established expert working groups ('Task Groups') for ten of the descriptors listed 
in Annex I of the MSFD (descriptors 1, 2, 3, 4, 5, 6, 8, 9, 10 and 11). These expert groups generated a report including the level of knowledge and development achieved for each descriptor, and suggesting the criteria, indicators and methodological standards for the definition of the GES [17, 18, 19, 20, 21, 22, 23, 24, 25, 26]. On the basis of these reports, and after consultation with stakeholders (including the Regional Sea Conventions), the EC adopted the Decision 2010/477/EU on criteria and methodological standards on good environmental status of marine waters [27], which specifies a total of 29 criteria and 56 indicators applicable to the eleven descriptors, which have to be properly developed to define and evaluate the degree to which the GES is attained, and the general conditions of application for these criteria and indicators.

Although it is assumed that this Decision indicates the methodological standards needed for the implementation of the MSFD, actually, Decision 2010/477/EU does not provide the necessary technical details that the practical implementation of marine strategies demands, leaving this task to the Member States. For instance, it is essential to make a proper selection of environmental variables indicative of the GES of ecosystems, and to establish the levels considered acceptable or desirable for them, as well as determining the appropriate spatial and temporal scales for these measurements to be considered valid. In fact, the EC recognizes a need for the review of the criteria and the further development of methodological standards set out in this Decision on the basis of new understanding and knowledge, in close coordination with the establishment of monitoring programs, once the evaluation of the elements reported by Member States in the first phase of development of marine strategies is completed. This review, as well as the review of MSFD's Annex III, is being carried out by the WG GES, which was asked to advice the MSFD Committee on this matter.

In accordance with MSFD's Article 12, the EC has evaluated whether the reports submitted by the Member States meet the requirements of the Directive, and has recently issued a report containing an analysis of the information submitted by the Member States and an evaluation of environmental status of European seas. Results from this evaluation [28, 29] indicate that, although most Member States determined GES for all descriptors under Article 9, and some established adequate and even ambitious definitions of GES, most of them did not go beyond the basic requirements of the MSFD (i.e. beyond existing commitments and obligations), and 
the level of detail in the GES definitions was not sufficient. Another matter of concern highlighted by the report is the lack of conceptual consistency between the initial assessment, the GES definitions and the determination of environmental targets, since the link between those elements was not identified by all Member States. In particular, some Member States did not make a clear distinction between the determination of GES and the targets, or did not take into account their initial assessment in developing targets, and a large group of countries have not set targets because of the lack of data and of adequate GES definitions. Also, the level of coherence in GES definitions and in targets set varied within and between regions and descriptors, but was in general low. In general, there was not a common understanding of GES, even at regional/subregional level, and conceptual problems were observed in the interpretation of criteria and indicators. In addition, over 20 different GES definitions were established across the EU, and were often not consistent, specific and/or measurable. Member States have established a wide variety of targets, different in number, type and nature (e.g. state, impact, pressure and/or operational targets). There have also been large differences in the perception of the role of targets in relation to GES. For instance, some Member States have developed environmental targets as a set of features corresponding to the desired state of the environment (i.e. equivalent to the GES), instead of the principles put forward to guide the process for achieving or maintaining the GES. In short, Member States have different ways of interpreting the implementation of the Directive, which results in a different level of ambition regarding prevention and protection of the marine environment, and leads to a significant degree of incoherence and lack of comparability among evaluations, without many common or comparable goals. These differences increase between marine regions and makes coordinated action and analysis difficult. According to the assessment system used, the documents presented by Spain obtained the best adequacy score in the Mediterranean region (60\%), and the second best score (after United Kingdom: 70\%) in the North-Atlantic region (60\%). All other Member States were below 55\%, with the lowest scoring being 9\% of the maximum.

\subsection{Regional Coordination}

Regional coordination is one of the main difficulties encountered in the implementation of the MSFD, and here the EC is supposed to make a significant effort during the next phases of the 
marine strategies. It is evident that the comparability among Member States’ assessments and the coherence between existing environmental instruments is essential to fulfill the requirements of the Directive, but this is hampered by the fact that environmental problems in territorial waters of a Member State may affect other Member States or third countries, or may have been originated in areas beyond their jurisdiction. For this reason, and in order to achieve the GES, it is of great importance the cooperation in developing marine strategies between Member States and between them and third countries whose territorial waters are within the same marine region or subregion.

Regional Sea Conventions should have an important role in these tasks, as recognized by the MSFD (Art. 6, MSFD), by providing the experience and media acquired during the last decades for the protection, conservation and management of the marine environment within marine regions. Regional Sea Conventions are supposed to serve as a basis for the coordination of the implementation process within marine regions or subregions, and may be used as a platform for organization and agreement with third countries, as required by the Directive. In fact, the EC report states that Regional Sea Conventions played an important role in the coordination of Member States, and that regional cooperation is well developed in all four EU marine regions [28, 29]. However, this task was done to a different extent in different countries (either the work of the Regional Sea Conventions came too late or was not always used in national reports to support the MSFD implementation process), which contributed to increase the lack of coherence within the EU and within the same region or subregion. In this sense, it has been agreed that Member States in the North East Atlantic region showed the highest level of coherence, although with considerable margin for improvement, whilst coherence between Member States in the Mediterranean and Black Sea regions was considered low. An additional factor to consider for the adequate coordination at the regional level is that several Member States are part of two Regional Sea Conventions.

The programs of the CIS working groups need to be precisely defined in order to indicate to the Regional Sea Conventions what is necessary to develop, and to progress as much as possible to guarantee the confluence of the schedules and timing of Regional Sea Conventions and Member States for MSFD. Member States should be able to agree, at the regional or subregional level, on a list of questions concerning the needs of monitoring, in line with the 
agreements of the Regional Sea Conventions, and, more importantly, to reach a common understanding about what is GES. The type of measures applied are probably of secondary importance (in terms of coordination), because different measures can lead to the same result. With these aims, future efforts should focus in improving the coordination between and within Regional Sea Conventions, to achieve a convergence and a logical association between what is done by the Regional Sea Conventions and what Member States need to do. At this moment, there is a lack of connection between the actions of Regional Sea Conventions and the MSFD reports made by Member States [28, 29]. Current cooperation between Regional Sea Conventions is also insufficient and limited to the exchange of information and knowledge, and to collaboration projects. The level of development of current monitoring programs differs considerably between Regional Sea Conventions, which is hindering the coordination process. OSPAR and HELCOM present the highest degree of development, with broad, wellestablished experience in monitoring, and agreed common methodologies, monitoring approaches, requirements and guidelines, between Contracting Parties [e.g. 4, 30, 31], which is reflected in the high level of integration and in their relevant implication in regional coordination for the implementation of the MSFD, compared with other Regional Sea Conventions. Thus, the Baltic Sea Action Plan (BSAP), adopted in HELCOM, is closely related to the MSFD, and outlines a strategy to restore de good ecological status of the Baltic marine environment by 2021 (http://helcom.fi/baltic-sea-action-plan). The MSFD is also explicitly considered by the OSPAR Environmental Strategy [32] and, in addition to the technical groups, it has been created an intersessional correspondence group within the OSPAR framework (ICG-MSFD), depending directly from the Coordination Group (CoG), to manage all aspects of OSPAR coordination for the MSFD implementation. On the other hand, the Mediterranean and Black Sea regions concentrate the main difficulties and problems, since political and socio-economic issues represent a challenge for the MSFD implementation, including the presence of third countries not obligated to implement the MSFD. In fact, the necessity of measures for stimulating the implementation process in the Mediterranean and Black Sea countries, as recognized by the EC, has lead to the creation of a Mediterranean branch of the Marine Strategy Coordination Group (MSCG-Med), to produce a road map and a specific program for Mediterranean countries, with the aim of solving the problems of 
implementation of the Directive in the Mediterranean. Nonetheless, in line with the MSFD requirements, the contracting parties of the Mediterranean Action Plan (MAP) decided to apply the Ecosystem Approach (EcAp) to the management of human activities in this region [33]. The EcAp implementation process undertaken by the MAP is similar to that developed at the European level for the MSFD, although there is not a formal link to this Directive. Eleven 'ecological objectives' were defined, with associated operational objectives and indicators to verify their compliance. As new elements, the process undertaken by the MAP sets targets for coastal ecosystems and for analyzing the influence of climate change on the marine environment (the latter was also included by Spain in the development of the marine strategies). The Strategic Action Plan for the Environmental Protection and Rehabilitation of the Black Sea (BS SAP) is also based on the application of the ecosystem approach but, as well as the EcAp, is not formally linked to the MSFD [34]. The integrated monitoring programme of the Black Sea Convention is not applied by each country to the same extent, since each country has its own legislation and, although some mandatory and recommended parameters have been indicated, they are not measured by all Member States. Moreover, monitoring activity is mainly focused in coastal waters, and sampling frequency depends strongly on funding allowance of each country.

The MSFD also includes specific provisions that promote actions among neighboring countries to coordinate their activities in order to give coherence to the marine strategies. This is seen as one of the main added values of MSFD with respect to other environmental directives [12]. In this regard, during the implementation process in Spain, there have been contacts, meetings and coordination activities, with France and Portugal, in the Northeast Atlantic region, and with France and Italy, in the Western Mediterranean subregion. These meetings were used to compare and harmonize the technical aspects of the implementation process of the MSFD, including the assessment of the current environmental status of each subregion and the approach taken for the definition of the GES, the establishment of environmental targets, the analysis of pressures and impacts, and the economic and social assessment. However, there has not been a real coordination of the countries' initial assessments, or of the definitions established to characterize the GES, beyond that provided by 
the CIS working groups. This lack of coordination and coherence has been identified by the EC as a flaw in the previous process of the Marine Strategies.

\section{Coordination in Spain}

The authority responsible for the implementation of the MSFD in Spain is the Ministry of Agriculture, Food and Environment (MAGRAMA). The MAGRAMA coordinates the marine strategies in collaboration with the involved administrations. The scientific support for the marine strategies was provided by the Spanish Oceanographic Institute (IEO), which is mentioned in the LPME as a resource and technical service of the General State Administration, through which the activities of the marine strategies will be implemented. The IEO carried out the initial assessment and the development of the eleven descriptors of good environmental status. The Center for Experimental Studies and Public Works (CEDEX) carried out the analysis of pressures and impacts, and a contracted environmental economist made the economic and social analysis. The technical platform formed by MAGRAMA, IEO, CEDEX and an environmental economist, is the Spanish Group of the Marine Strategy.

Article 22 of the LPME establishes two inter-administrative coordination tools: the Marine Strategy Inter-ministerial Commission, and the cooperation between the General State Administration and the Autonomic Communities, according to their competences in the marine environment.

The Marine Strategy Inter-ministerial Commission was created by Royal Decree [35], following approval by the Council of Ministers. This Commission is a forum for coordination, discussion and decision-making within the General State Administration, for all matters related to marine protection and planning. The Commission integrates all organs of the General State Administration with competences on the marine environment, and is chaired by the Secretary of State for the Environment. The functions of this Commission are: to analyze, evaluate and guide the exchange of information related to the marine environment, to carry out the analysis of the different components of the marine strategies, and track the activities of different ministerial departments in compliance thereof. 
The coordination between the General State Administration and the Autonomic Communities will be achieved through the creation of Marine Strategies Monitoring Committees. A Committee for each marine demarcation will be established. Its constitution, which is underway, will be done by ministerial order, and board members from the state and autonomic administrations will be represented. The functions of these committees will be the follow-up of the implementation of marine strategies, the coordination and cooperation in the implementation of monitoring programs, and the coordination of the proposal of actions to be included in the programs of measures. It will be necessary to establish a link between the two bodies, which will be built by the designation of a representative of the Marine Strategy Interministerial Commission as a member of the Marine Strategies Monitoring Committees.

\section{Next Steps}

\subsection{Monitoring programs}

The next task to be addressed in order to implement marine strategies is the elaboration of the monitoring programs (Article 11, MSFD). The general aim of these monitoring programs is the continuous assessment of the status of the marine environment, and will be used to estimate the distance between the environmental status and the GES, based on the elements listed in Annex III and following the principles contained in Annex V of the MSFD. Also, monitoring programs are expected to determine the appropriate indicators to estimate the achievement of the environmental targets and the impact of the program of measures, and confirm that the corrective actions are effective. Thus, the cause of change could be established and the potential remedial measures to restore the GES could be identified.

Monitoring programs must be compatible and consistent within the marine regions or subregions, so it is advisable to organize the information at this level. To guarantee a common understanding of GES, common methodologies and procedures for the establishment of GES thresholds and limits, especially in relation to background or reference levels, are needed. If the comparability of approaches and assessment methods has to be guaranteed at the scale of region or subregion, it will be necessary to develop the technical specifications and standardized methods for monitoring, including an agreed core set of indicators, at this level. 
The elaboration of monitoring programs presents the occasion to leave behind the existing differences, so it may be useful to establish certain minimum requirements or benchmarks. An important requirement is that MSFD monitoring programs have to be structured on the basis of existing programs, so that activities are not duplicated, including those aspects of the environmental status of the marine environment that are not covered by other initiatives. Therefore, the environmental monitoring performed under other directives (e.g. WFD, Habitats Directive, Birds Directive) has to be used and optimized, since many of the MSFD's indicators are derived from those directives, as well as from the environmental monitoring conducted by Regional Sea Conventions for the protection of the marine environment, and from the environmental monitoring performed under other international treaties and obligations (e.g. EU Common Fisheries Policy, Maritime Spatial Planning, Data Collection Framework). Most Member States have recognized the role developed by other policies and agreements in MSFD implementation, but have made a limited use of them and/or integrated them into the marine strategies to a very different extent. In many cases, the integration with the European legal framework was insufficient, and it has not been clarified how these legislative provisions inter-relate [28, 29].

A broad range of European and international policies (pollution, biodiversity, fisheries, maritime traffic, etc.) are related with the MSFD. Among them, the EU Integrated Maritime Policy has the objective of promoting the growth of the maritime economy and the coastal regions as well as guaranteeing the protection of marine ecosystems and the sustainable development of the seas and oceans of the EU [36]. The Common Fisheries Policy (CFP) is the basic regulatory tool for managing European fishing fleets and for conserving fish stocks, aiming to ensure that fishing and aquaculture are environmentally, economically and socially sustainable and that they provide a source of healthy food for EU citizens [37]. The relationship between the CFP and the MSFD is very narrow. The EU also promotes a policy to achieve greater integration of marine and maritime research, the European strategy for marine and maritime research [38]. Through this instrument, the EU plans to improve the research activities in order to join and consolidate the protection of marine ecosystems with the development of sustainable maritime activities, which contributes to the implementation process of the MSFD. The purpose of the Directive 2000/60/EC, or Water Framework 
Directive, is to establish a framework for the protection of inland surface waters, transitional waters, coastal waters and groundwater [10]. This Directive evaluates the status of water bodies in terms of their ecological and chemical status in order to prevent deterioration, protect and restore all bodies of surface water and progressively reduce pollution with the aim of achieving good status thereof. Therefore, there is not only an overlap in the geographic area addressed by WFD and DMEM, but also in the elements or issues to evaluate. The European biodiversity policy is built on the basis of the Birds [8] and Habitats [9] directives. Both directives are very present in the MSFD. In fact, the MSFD indicates that the establishment of marine protected areas, including those already designated by both directives, constitutes an important contribution to the achievement of GES. Also, the main aim of the MSFD of achieving or maintaining the GES in the marine environment by 2020, is in line with the commitments established in the European Biodiversity Strategy: "Halting the loss of biodiversity and the degradation of ecosystem services in the EU by 2020 and restoring them in so far as feasible..." [39]. Other directives and regulations partially linked with the MSFD are the Bathing Water Directive [40], the Nitrates Directive [41], the Urban Waste Water Directive [42], the Environmental Liability Directive [43], the Environmental Assessment Directives (Environmental Impact Assessment Directive [44], the Strategic Environmental Assessment Directive [45]) and the Directive on Integrated Pollution Prevention and Control [46].

Besides the Regional Sea Conventions, other relevant international agreements applicable are the conventions on prevention of marine pollution such as: the London Convention (1975), the International Convention for the Prevention of Pollution from Ships (MARPOL) (1973), the International Convention on Oil Pollution Preparedness, Response and Co-operation (1990), the International Convention for the Control and Management of Ships' Ballast Water and Sediments (2004); the conventions related to biodiversity such as: the United Nations Convention on Biological Diversity (1992) or Rio Convention, the Convention on Wetlands of International Importance especially as Waterfowl Habitat, or Ramsar Convention (1971), the Convention on the conservation of European wildlife and natural habitats (1979), or Bern Convention, the Convention on the Conservation of Migratory Species of Wild Animals (1979), or Bonn Convention, the Convention on International Trade in Endangered Species of 
Wild Fauna and Flora (1975), or CITES Convention, and the UNESCO Convention concerning the Protection of the World Cultural and Natural Heritage (1975); the agreements for the protection and regulation of fisheries resources such as: the Convention on Fishing and Conservation of the Living Resources of the High Seas (1958), the International Commission for the Conservation of Atlantic Tunas (1969), the International Baltic Sea Fishery Commission (1973), the North East Atlantic Fisheries Commission (1982), the Convention for the Conservation of Salmon in the North Atlantic Ocean (1982), the FAO's Code of Conduct for Responsible Fisheries (1995), or the Reykjavik Declaration on Responsible Fisheries in the Marine Ecosystem (2001).

Obviously, monitoring programs must be consistent with the initial assessment and the GES descriptors, however, these programs should also be flexible, to allow dealing with new or emerging problems. It is also recommended to follow an approach based on risk analysis in the design of the MSFD monitoring programs, identifying sensitive areas or areas subjected to specific pressures, where to focus the efforts of environmental monitoring. This is especially relevant for countries with a large sea area, such as Spain. It is essential again the coordination of Member States sharing a marine region or subregion, as well as the creation of a framework at the European level to facilitate the flow, use and storage of information in an interoperable way.

\section{Concluding remarks}

Despite the MSFD constitutes a milestone for the protection and management of European seas -since not only aims to protect marine ecosystems, but also to manage human activities in order to achieve the sustainable use of the seas- also shows some gaps and inaccuracies that should be mentioned. As indicated above, the Directive, like the Decision 2010/477/EU, is not sufficiently accurate at the technical level (starting with the definition of the GES), and Member States have been responsible for developing the necessary tools to carry out the practical implementation of the marine strategies. This can pose an additional difficulty when comparing the evaluations of different states. Taking into account that the marine areas are shared between different Member States and third countries, major coordination efforts are 
required in order to agree on common objectives in the pursuit of GES. Another inaccuracy of this Directive results from the flexibility when requiring Member States to achieve or maintain the GES, since a number of special cases are established where a given member state would not be required to comply with the requirements of the MSFD (e.g. irreversible loss of habitats, disproportionate costs). This flexibility can be risky, in some way, since it allows for a relaxation of Member States both in the definition of the GES and in the establishment of environmental targets. Moreover, there is some ambiguity about whether the major aim of the Directive, according to which Member States have to achieve the GES in 2020, is or not legally binding. This objective, mentioned in the first article of the MSFD, is formulated as follows: "This Directive establishes a framework within which Member States shall take the necessary measures to achieve or maintain good environmental status in the marine environment by the year 2020 at the latest“. Therefore, the obligation of the Member States would be to 'take the necessary measures' to achieve or maintain the GES, but not to actually 'achieve or maintain the GES'.

Although the importance of achieving the sustainable management of the seas is unquestionable, do Member States really have the necessary tools to carry it out? As mentioned above, several environmental management tools have been put in place that Member States can use, articulating and complementing them with specific actions needed to meet the requirements of the MSFD. At first glance, it may seem that these instruments would be sufficient to meet most of the demands of the MSFD, and that only would need to be supplemented with some specific actions. However, this appears to be far from reality (e.g. [30]). In fact, the heterogeneity of these mechanisms and the low coordination between them highlighted the need (until the entry into force of the MSFD) of legislation for the protection of European seas in an integrated manner. Indeed, both the material and/or the geographic scope of the MSFD are broader than that provided by previous standards and management mechanisms (see [12] for a detailed analysis of the added value of MSFD). For example, in the case of the Water Framework Directive, the monitoring methodology is different and is not applicable to MSFD objectives, since it works at the scale of water masses, and harmonized approaches and strategies would be needed to coordinate both directives. A detailed comparison between both MSFD and WFD has been provided elsewhere [e.g. 47]. Moreover, 
not all biotic and abiotic elements and pressures of the MSFD are included in the aforementioned initiatives, and the MSFD covers all waters under the sovereignty and jurisdiction of each member state, including territorial waters and EEZs. Therefore, it will be required to carry out the environmental monitoring in offshore areas, which is not provided by other environmental management tools, and constitutes one of the major forthcoming challenges. Furthermore, besides other added values with respect to previous instruments, such as the mentioned demand of regional cooperation among Member States, the MSFD reinforces and enhances previous conservation measures, promotes the application of several environmental principles such as the 'ecosystem approach', the 'precautionary principle', or the 'adaptive management', and introduces a strict timetable that Member States must comply.

But the extent of the added value of the MSFD with respect to other environmental management instruments is difficult to establish at this moment, and is conditioned by how the practical implementation of the Directive is performed. In short, success in achieving the objectives set out by MSFD will depend on whether to achieve or maintain the GES will be established as an immovable pillar on which to settle the sustainable use of the marine environment. Here, the key will be the implementation of an adequate monitoring program, and the application by the state of an ambitious program of measures. The problem is that the MSFD does not specify the management measures that states must adopt (although gives some indications on what Member States are to base the measures) and, as mentioned above, suffers from some flexibility when requiring compliance by the Member States. Depending on how these exceptions are interpreted, this could lead to a relaxation by a member state in the implementation of the program of measures.

Finally, although the MSFD establishes that the marine strategies will be 'supported by existing Community financial instruments' and that 'The programmes drawn up by the Member States shall be co-financed by the EU in accordance with existing financial instruments' (Art. 22, MSFD), as a matter of fact, Member States must count on their budgets for the implementation of the MSFD. In Spain, it remains to be seen whether the current socioeconomic situation, with massive cuts in Research and Development, will provide a promising future for marine strategies. 


\section{Acknowledgements}

This work has been conducted within the framework of a Fund Management Agreement between the IEO and the Spanish Ministry of Agriculture, Food an Environment (2010-2012).

\section{References}

[1] Steffen W, Sanderson A, Tyson PD, Jäger J, Matson P, Moore III B, Oldfield F, Richardson K, et al. Global change and the earth system: A planet under pressure. The IGBP global change series. Berlin: Springer-Verlag; 2004.

[2] European Environment Agency. Europe’s environment. The fourth assessment 2007; $239-240$.

[3] UNEP and IOC-UNESCO. An Assessment of Assessments, Findings of the Group of Experts. Start-up Phase of a Regular Process for Global Reporting and Assessment of the State of the Marine Environment including Socio-economic Aspects; 2009. ISBN 978-92-807-2976-4.

[4] OSPAR Commission. Quality Status Report 2010. London: OSPAR Commission, 176 pp; 2010.

[5] Elliott M, Burdon D, Hemingway KL, Apitz SE. Estuarine, coastal and marine ecosystem restoration: Confusing management and science - A revision of concepts. Estuarine, Coastal and Shelf Science 2007, 74: 349-366.

[6] Marques JC, Basset B, Brey T, Elliott M. The ecological sustainability trigon - A proposed conceptual framework for creating and testing management scenarios. Marine Pollution Bulletin 2009, 58: 1773-1779.

[7] UNCLOS. http://www.un.org/Depts/los/convention_agreements/convention_overview_convention. htm. 1982.

[8] European Union. Council Directive 79/409/EEC of 2 April 1979 on the conservation of wild birds. Official J. Eur. Union 1979; L103: 1-18. 
[9] European Union. Council Directive 92/43/EEC of 21 May 1992 on the conservation of natural habitats and of wild fauna and flora. Official J. Eur. Union 1992; L206: 7-50.

[10] European Union. Directive 2000/60/EC of the European Parliament and of the Council of 23 October 2000, establishing a framework for community action in the field of Water Policy (Water Framework Directive). Official J. Eur. Union 2000; L327: 1-72.

[11] Mee LD, Jefferson RL, Laffoley Dd'A, Elliott M. How good is good? Human values and Europe's proposed Marine Strategy Directive. Marine Pollution Bulletin 2008, 56: 187-204.

[12] Trouwborst A, Dotinga HM. Comparing European instruments for marine nature conservation: the OSPAR Convention, the Bern Convention, the Birds and Habitats Directives, and the added value of the Marine Strategy Framework Directive. European Energy and Environmental Law Review 2011; 20: 129-149.

[13] European Union. Decision 1600/2002/EC of the European Parliament and of the Council laying down the Sixth Community Environment Action Programme. Official J. Eur. Union 2002; L 242: 1-15.

[14] European Union. Directive 2008/56/EC of the European Parliament and of the Council of 17 June 2008, establishing a framework for community action in the field of marine environmental policy (Marine Strategy Framework Directive). Official J. Eur. Union 2008; L164: 19-40.

[15] Spain. Ley 41/2010, de 29 de diciembre, de protección del medio marino. BOE 31 de 30/12/2010; 2010.

[16] Spain. Resolución de 13 de noviembre de 2012, de la Secretaría de Estado de Medio Ambiente, por la que se publica el Acuerdo del Consejo de Ministros de 2 de noviembre de 2012, por el que se aprueban los objetivos ambientales de las estrategias marinas españolas. BOE 285 de 27/11/2012; 2012.

[17] Cochrane SKJ, Connor DW, Nilsson P, Mitchell I, Reker J, Franco J, Valavanis V, Moncheva S, Ekebom J, Nygaard K, Serrão Santos R, Narberhaus I, Packeiser T, van de 
Bund W, Cardoso AC. Marine Strategy Framework Directive Task Group 1 Report Biological diversity 2010; EUR 24337 EN.

[18] Olenin S, Alemany F, Cardoso AC, Gollasch S, Goulletquer P, Lehtiniemi M, McCollin T, Minchin D, Miossec L, Occhipinti Ambrogi A, Ojaveer H, Rose Jensen K, Stankiewicz M, Wallentinus I, Aleksandrov B. Marine Strategy Framework Directive Task Group 2 Report Non-indigenous species 2010; EUR 24342 EN.

[19] Piet GJ, Albella AJ, Aro E, Farrugio H, Lleonart J, Lordan C, Mesnil B, Petrakis G, Pusch C, Radu G, Rätz HJ. Marine Strategy Framework Directive Task Group 3 Report Commercially exploited fish and shellfish 2010; EUR 24316 EN.

[20] Rogers S, Casini M, Cury P, Heath M, Irigoien X, Kuosa H, Scheidat M, Skov H, Stergiou K, Trenkel V, Wikner J, Yunev O. Marine Strategy Framework Directive Task Group 4 Food webs 2010; EUR 24343 EN.

[21] Ferreira JG, Andersen JH, Borja A, Bricker SB, Camp J, Cardoso da Silva M, Garcés E, Heiskanen AS, Humborg C, Ignatiades L, Lancelot C, Menesguen A, Tett P, Hoepffner N, Claussen U. Marine Strategy Framework Directive Task Group 5 Report Eutrophication 2010; EUR 24338 EN.

[22] Rice J, Arvanitidis C, Borja A, Frid C, Hiddink J, Krause J, Lorance P, Ragnarsson SÁ, Sköld M, Trabucco B. Marine Strategy Framework Directive Task Group 6 Report Seafloor integrity 2010; EUR 24334 EN.

[23] Law R, Hanke G, Angelidis M, Batty J, Bignert A, Dachs J, Davies I, Denga Y, Duffek A, Herut B, Hylland K, Lepom P, Leonards P, Mehtonen J, Piha H, Roose P, Tronczynski J, Velikova V, Vethaak D. Marine Strategy Framework Directive - Task Group 8 Report Contaminants and pollution effects 2010; EUR 24335 EN.

[24] Swartenbroux F, Albajedo B, Angelidis M, Aulne M, Bartkevics V, Besada V, Bignert A, Bitterhof A, Hallikainen A, Hoogenboom R, Jorhem L, Jud M, Law R, Licht Cederberg D, McGovern E, Miniero R, Schneider R, Velikova V, Verstraete F, Vinas L, Vlad S. Marine Strategy Framework Directive - Task Group 9 Report Contaminants in fish and other seafood 2010; EUR 24339 EN. 
[25] Galgani F, Fleet D, Van Franeker J, Katsanevakis S, Maes T, Mouat J, Oosterbaan L, Poitou I, Hanke G, Thompson R, Amato E, Birkun A, Janssen C. Marine Strategy Framework Directive - Task Group 10 Report Marine Litter 2010; EUR 24340 EN.

[26] Tasker ML, Amundin M, Andre M, Hawkins A, Lang W, Merck T, Scholik-Schlomer A, Teilmann J, Thomsen F, Werner S, Zakharia M. Marine Strategy Framework Directive - Task Group 11 Underwater noise and other forms of energy 2010; EUR 24341 EN.

[27] European Union. Commission Decision 2010/477/EU of 1 September 2010 on criteria and methodological standards on good environmental status of marine waters. Brussels: Official J. Eur. Union 2010; L232: 14-24.

[28] European Union. Report from the Commission to the Council and the European Parliament. The first phase of implementation of the Marine Strategy Framework Directive (2008/56/EC). The European Commission's assessment and guidance. COM/2014/097 final. http://ec.europa.eu/environment/marine/eu-coast-and-marinepolicy/implementation/reports_en.htm.

[29] European Union. Commission staff working document. Annex accompanying the document Commission Report to the Council and the European Parliament. The first phase of implementation of the Marine Strategy Framework Directive (2008/56/EC). The European Commission's assessment and guidance. SWD/2014/049 final. http://ec.europa.eu/environment/marine/eu-coast-and-marinepolicy/implementation/reports_en.htm.

[30] Zampoukas N, Henna P, Bigagli E, Hoepffner N, Hanke G, Cardoso AC. Marine monitoring in the European Union: How to fulfill the requirements for the marine strategy framework directive in an efficient and integrated way. Marine Policy 2013; 39: 349-351.

[31] van Leeuwen J, van Hoof L, van Tatenhove J. Institutional ambiguity in implementing the European Union Marine Strategy Framework Directive. Marine Policy 2012; 36: 636-643. 
[32] OSPAR Commission. The North-East Atlantic Environment Strategy; Strategy of the OSPAR Commission for the Protection of the Marine Environment of the North-East Atlantic 2010-2020 (OSPAR Agreement 2010-3). London: OSPAR Commission; 2010.

[33] UNEP/MAP. Implementation of the ecosystem approach to the management of human activities that may affect the Mediterranean marine and coastal environment. Decision IG 17/6. Annex V. Decisions of the $15^{\text {th }}$ Meeting of the Contracting Parties of the Barcelona Convention, Almería, Spain, 2008.

[34] Black Sea Commission. Strategic Action Plan for the Environmental Protection and Rehabilitation of the Black Sea; Adopted in Sofia, Bulgaria, 17 April 2009. Bucharest: Black Sea Commission; 2009.

[35] Spain. Real Decreto 715/2012, de 20 de abril, por el que se crea la Comisión Interministerial de Estrategias Marinas. BOE 113, de 11/05/2012; 2012.

[36] European Union. COM (2007) 574 and 575. Communication from the Commission to the European Parliament, the Council, the European Economic and Social Committee and the Committee of the Regions: An Integrated Maritime Policy for the European Union.

[37] European Union. Regulation (EU) No 1380/2013 of the European Parliament and of the Council of 11 December 2013 on the Common Fisheries Policy, amending Council Regulations (EC) No 1954/2003 and (EC) No 1224/2009 and repealing Council Regulations (EC) No 2371/2002 and (EC) No 639/2004 and Council Decision 2004/585/EC. Official J. Eur. Union 2013; L354: 22-61.

[38] European Union. COM (2008) 534. Communication from the Commission to the Council, the European Parliament, the European Economic and Social Committee and the Committee of the Regions. A European Strategy for Marine and Maritime Research. A coherent European Research Area framework in support of a sustainable use of oceans and seas.

[39] European Union. COM (2011) 244. Communication from the Commission to the European Parliament, the Council, the Economic and Social Committee and the 
Committee of the Regions: Our life insurance, our natural capital: an EU biodiversity strategy to 2020.

[40] European Union. Directive 2006/7/EC of the European Parliament and of the Council of 15 February 2006 concerning the management of bathing water quality and repealing Directive 76/160/EEC. Official J. Eur. Union 2006; L64: 37-51.

[41] European Union. Council Directive 91/676/EEC of 12 December 1991 concerning the protection of waters against pollution caused by nitrates from agricultural sources. Official J. Eur. Union 1991; L375: 1-8.

[42] European Union. Council Directive 91/271/EEC of 21 May 1991 concerning urban waste water treatment (amended by Directive 98/15/EC). Official J. Eur. Union 1991; L135: 40-52.

[43] European Union. Directive 2004/35/CE of the European Parliament and of the Council of 21 April 2004 on environmental liability with regard to the prevention and remedying of environmental damage. Official J. Eur. Union 2004; L143: 56-75.

[44] European Union. Council Directive 85/337/EEC of 27 June 1985 on the assessment of the effects of certain public and private projects on the environment (EIA Directive). Official J. Eur. Union 1985; L75: 40-48.

[45] European Union. Directive 2001/42/EC of the European Parliament and of the Council of 27 June 2001 on the assessment of the effects of certain plans and programmes on the environment. Official J. Eur. Union 2001; L197: 30-37.

[46] European Union. Council Directive 96/61/EC of 24 September 1996 concerning integrated pollution prevention and control. Official J. Eur. Union 2001; L257: 26-40.

[47] Borja A, Elliott M, Carstensen J, Heiskanen A-S, van de Bund W. Marine management towards an integrated implementation of the European Marine Strategy Framework and the Water Framework Directives. Marine Pollution Bulletin 2010, 60: 2175-2186. 


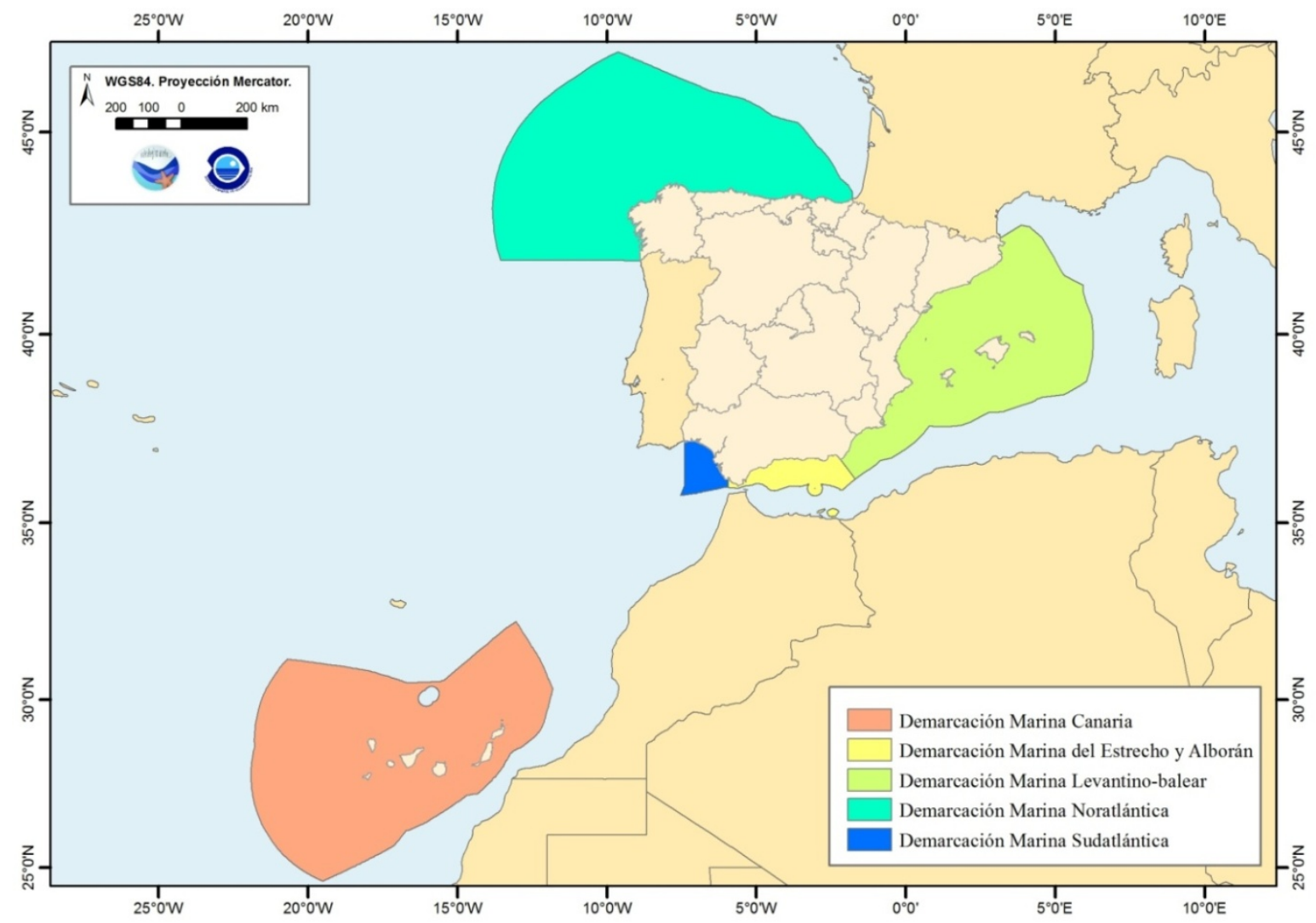

Figure 1. Orientative map of the Spanish marine demarcations (courtesy of Olvido Tello, IEO). 


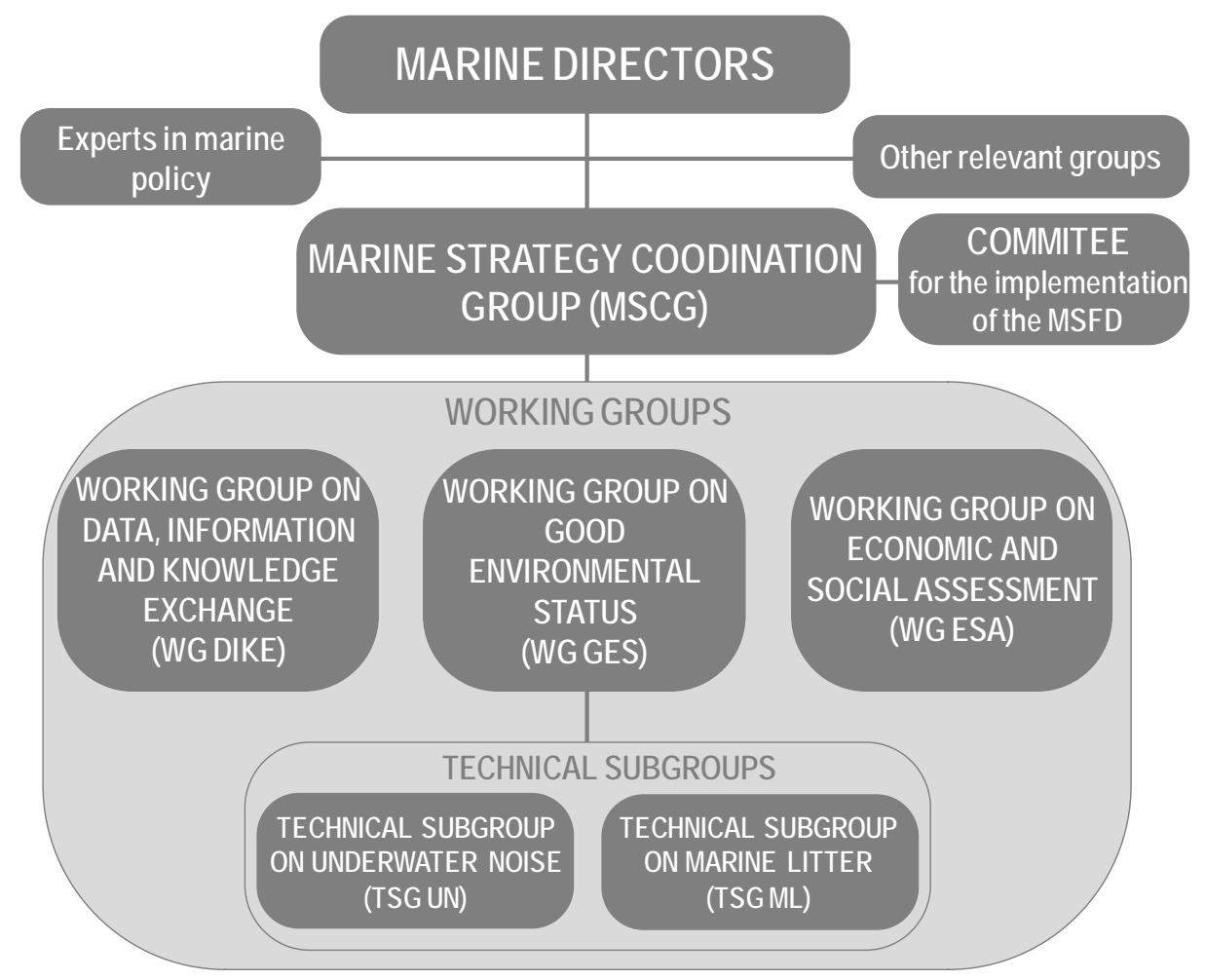

Figure 2. Structure of the MSFD's Common Implementation Strategy (modified from http://ec.europa.eu/). 